\title{
静岡県奨励品種の一番茶新芽の生育，硬化および成分特性
}

\author{
静岡県農林技術研究所茶業研究センター* \\ 鈴木利和 ${ }^{\dagger} \cdot$ 大石哲也
}

(平成27年 9 月 8 日受理)

\section{Characteristics in New Shoot Growth, Hardening and Component of First Crop of Tea Cultivars Recommended in Shizuoka Prefecture}

\author{
Toshikazu Suzuki and Tetsuya Oishi \\ Shizuoka Research Institute of Agriculture and Forestry, Shizuoka Tea Research Center
}

Summary

This study investigated the cultivar differences in new shoot growth, hardening of leaves and component of first crop of five tea cultivars. 'Tsuyuhikari' had more opened leaves per day than the other four cultivars. The hardening of new leaves, the rate of increase in the yield per unit area and decrease in total nitrogen content in the new shoot differed with the cultivar. The hardening degree of the middle or lower leaf at the 4-5th leaf stage of 'Tsuyuhikari' and 'Kousyun' was lower and that of 'Yamanoibuki' and 'Okuhikari' was higher than that of 'Yabukita'. The total nitrogen content in the new shoot of 'Tsuyuhikari' was higher at the optimum plucking time and decreased at a lower rate than that of 'Yabukita'.

Key words : component, cultivar, growth, hardening, new shoot

キーワード：成分，品種，生育，硬化，新芽

\section{1 緒 言}

チャの育種過程では, 早晚性や樹姿等の一般的特性, 収量性, 荒茶の品質・成分等が評価され，品種登録に伴 い具体的な特性や特徴が示される。生産者はこの情報に 基づき, 導入の可否, 導入場所や生産計画を検討し, 導 入後に現地ほ場で品種の特性や特徵を確認しつつ, 自己 の経営方針に合わせて適切な栽培管理や加工方法を決定
している。

品種が持つ固有の特性のうち, 生育に伴う新芽の硬化 特性や化学成分の変動特性は, 摘採適期の判定や製茶品 質に大きな影響を及ぼす要素である。しかしながら，こ れらの特性については, 評価基準や簡易な評価手法が確 立していないため, 育種段階で詳細なデー夕を集積する のが困難であり, 生産現場への導入後も特性を確認する ための客観的な評価デー夕を得にくいのが実情である。 これまでにチャの葉の硬化度を測定するための幾つかの 
手法が考案され ${ }^{1 \sim 4)}$, 打ち抜き抵抗測定器 ${ }^{5)}$ を用いて 主に国（茶業試験場または野菜茶業試験場）育成品種に ついて生育に伴う新芽の硬化度や化学成分の変動特性が

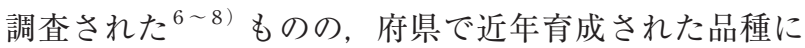
ついての報告例は極めて少ない。

本研究では，品種普及と経営向上に資することを目的 として, 静岡県奨励品種のうち比較的近年に育成され, 新芽の特性が十分に解明されていないつつゆひかり，香 駿，山の息吹，おくひかり’を対象として，新芽の生育 速度，生育に伴う新芽葉の硬化度および全窒素含有率の 変動を解析し, ‘やぶきた’ との比較から, 新芽の生育, 硬化および成分特性を明らかにした。

\section{2 材料および方法}

\section{1 供試茶園および品種}

静岡県農林技術研究所茶業研究センター（静岡県菊川 市倉沢）内の品種見本園（B6ほ場）を供試茶園とした。 供試品種は，静岡県奨励品種のうち，比較的近年育成さ れた 4 品種と対照品種の‘やぶきた’とした（表 1 )。 1 品種当たり $18 \mathrm{~m}^{2}$ の区画を試験に用いた。

\section{2 新芽の開葉数}

2011年および2012年の 3 月下旬に，各品種の株面から 平均的な大きさの側芽 20 芽を選定しラベルを付けた。 4 月15日（“おくひかり’のみ 4 月20日）から 5 日おきに 各新芽の開葉数を計測し，20芽の平均值を算出した。調 査期間は, 各品種とも開葉数が概ね 1 ～枚となるよう に設定した。調査回数は 5 回（2012年の ‘つゆひかり’ のみ 4 回）とした。前年の秋整枝は，2010年10月 9 日お よび2011年10月 8 日に行った。

\section{3 新芽葉の硬化度}

\section{(1) 積算日射量と硬化度の関係}

2011年 3 月下旬に, 各品種の株面から平均的な大きさ の側芽40芽を選定しラベルを付けた。一番茶生育期に各
新芽の全ての新葉について開葉日を調査した後, 対象新 芽の概ね $70 \%$ 程度が出開いた生育後期に新芽を基部から 採取し, 打ち抜き抵抗測定器 (サン科学社製, レオメー ターCR-200D）を用いて各葉の打ち抜き抵抗值（硬化度） を測定した。アダプターは直径 $2 \mathrm{~mm}$ の先の尖っていな い円柱形のものを使用した。測定位置は葉脈を避けた葉 中央付近の葉身部分として各葉 1 ケ所を測定した。また, ほ場内に日射計(ウイジン社製，UIZ-PCM01)を設置し， 5 分おきの日射量データ (瞬間值) から 1 日あたりの積 算日射量を算出した。調査区の秋整枝は2010年10月 9 日 または10月24日に行った。

渡辺 ${ }^{8)}$ は, 新葉の硬化度の推移はロジスティック曲 線で近似でき, 積算日射量との相関が高いことを報告し ている。そこで渡辺の手法を参考に, 各葉の開葉日から 採取日までの積算日射量を時間軸としたロジスティック 曲線に当てはめることにより硬化度との関係を解析し た。解析ソフトはSTATISTICA（スタットソフトジャ パン社製）を使用した。

\section{(2) 生育ステージおよび葉位と硬化度との関係}

2012年の一番茶生育期において, 各品種の概ね 3 葉期 から 6 葉期の間に新芽を採取した。この期間中に， 1 心 3 葉， 1 心 4 葉， 1 心 5 葉， 1 心 6 葉芽（いずれも出開 いていない新芽を供試）を 5 本ずつ基部から採取し, 各 新芽葉の硬化度を葉位別に測定した。硬化度の測定は, 2011年の試験と同様の機器および方法で行った。

\section{4 生育に伴う新芽の全窒素含有率の変動}

\section{(1) 摘芽重と全窒素含有率との関係}

2011年に一番茶新芽の開葉数が概ね 3 枚となった時期 から 2 ～ 3 日おきに枠摘み $(20 \times 20 \mathrm{~cm}$, 各品種 4 枠 $/$ 回）を行った。枠摘みの摘芽位置は前年秋整枝位置か ら $1.5 \mathrm{~cm}$ 上とした。“山の息吹’は 4 月 28 日～ 5 月 10 日， ‘つゆひかり，やぶきた’は 4 月30日〜 5 月 12 日，“香 駿’は 5 月 4 日〜 5 月 15 日，“おくひかり’は 5 月 5 日 〜 5 月 16 日の期間に, 計 5 回の枠摘みを行なった。枠摘 み後, 摘芽を電子レンジで殺青し, $70^{\circ} \mathrm{C}$ で 24 時間通風乾

表 1 供試品種の概要

\begin{tabular}{cccccc}
\hline 品種名 & 早晚性 & 樹勢 & 樹姿 & 収量性 & $\begin{array}{c}\text { 供試茶園へ } \\
\text { の定植年 }\end{array}$ \\
\hline 山の息吹 & 早生 & 強 & やや直立型 & やや多 & 2001 \\
つゆひかり & やや早生 & 極強 & 中間型 & 多 & 2001 \\
やぶきた & 中生 & やや強 & やや直立型 & やや多 & 1985 \\
否駿 & 中生 & 中 & 開張型 & 多 & 2000 \\
おくひかり & 晚生 & 強 & 直立型 & や多 & 1985 \\
\hline
\end{tabular}


燥 (SANYO社製, MOV-212P) した後, 摘芽重(乾燥重) を測定した。試料を粉砕し, 元素分析計（住化分析セン ター社製, SUMIGRAPH NC-22）を用いて全窒素含有 率を測定した。

\section{(2) 生育ステージと全窒素含有率の関係}

2012年の一番茶生育期において, 各品種の概ね 3 葉期 から 6 葉期の間に新芽を採取した。この期間中に， 1 心 3 葉， 1 心 4 葉， 1 心 5 葉， 1 心 6 葉芽（いずれも出開 いていない新芽を供試）を10本ずつ基部から採取し（3 反復)，電子レンジで殺青した後，2011年の試験と同様 の方法で, 乾燥, 粉砕して全窒素含有率を測定した。

\section{3 結 果}

\section{1 新芽の開葉速度}

2011年の各品種の開葉数の推移を図 1 に示した。独立 変数を 4 月15日からの経過日数, 従属変数を開葉数とし て回帰直線を作成した結果，1 日当たりの開葉数は，‘つ ゆひかり’が 0.25 枚，“山の息吹，やぶきた，おくひかり’ が $0.21 〜 0.22$ 枚, “香駿”が 0.20 枚となった。回帰直線の 平行性検定を行なった結果, ‘やぶきた’と比較して‘つ ゆひかり’は傾きが有意に大きく開葉速度が最も速かっ た。また，“香駿”は傾きが有意に小さかった。

2012年の各品種の開葉数の推移を図 2 に示した。“山

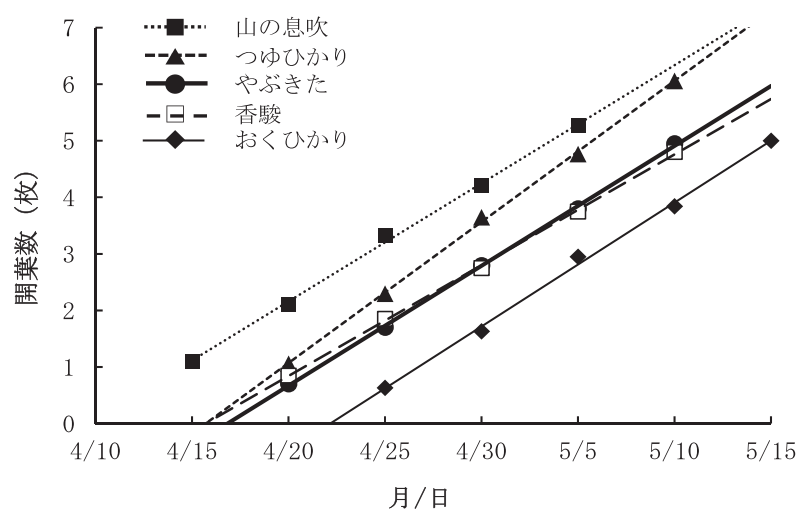

図 1 各品種の開葉数の推移（2011年）

回帰式の独立変数 $\mathrm{x}$ は起算日 $4 / 15$ からの経過日数, 従属変数 は開葉数の 20 芽平均值とした。

$$
\begin{array}{lllll}
\text { 山の息吹 } & \mathrm{y}=0.209 \mathrm{x}+1.11 & (\mathrm{n}=5, & \left.\mathrm{r}^{2}=0.998\right) & \mathrm{bc} \\
\text { つゆかり } & \mathrm{y}=0.249 \mathrm{x}-0.18 & (\mathrm{n}=5, & \left.\mathrm{r}^{2}=0.999\right) & \mathrm{a} \\
\text { やぶきた } & \mathrm{y}=0.212 \mathrm{x}-0.39 & (\mathrm{n}=5, & \left.\mathrm{r}^{2}=0.999\right) & \mathrm{b} \\
\text { 香駿 } & \mathrm{y}=0.196 \mathrm{x}-0.14 & (\mathrm{n}=5, & \left.\mathrm{r}^{2}=0.999\right) & \mathrm{c} \\
\text { おくひかり } & \mathrm{y}=0.219 \mathrm{x}-1.57 \quad(\mathrm{n}=5, & \left.\mathrm{r}^{2}=0.998\right) & \mathrm{b}
\end{array}
$$

の息吹’ は, 3 月下旬から 4 月上旬の低温の影響を受け て萌芽期前後の生育が抑制され 1 葉期が遅れたため, そ の後の開葉数の推移は, ‘やぶきた, 香駿” と類似した 傾向を示した。2011年と同様に回帰直線を作成した結果, 1 日当たりの開葉数は, ‘つゆひかり’が 0.26 枚, ‘おく ひかり’が 0.25 枚, ‘山の息吹, やぶきた，香駿’が 0.23 枚であった。回帰直線の平行性検定を行なった結果, 品 種間差異は認められなかった。一番茶新芽の 1 葉期 における開葉速度は，2011年では ‘やぶきた’ と比較し て ‘つゆひかり が有意に速く, “香駿” が有意に遅か った。2012年は有意な品種間差異が認められなかったが, 開葉速度が速い順に，つゆひかり>おくひかり>やぶ きたう山の息吹 >香駿” となる点は2011年と一致した。

\section{2 新芽葉の硬化度}

各品種の積算日射量と硬化度との関係を図 3 に示し た。独立変数を積算日射量, 従属変数を硬化度 (打ち抜 き抵抗值）としたロジスティック曲線に当てはめたとこ ろ, 各品種とも開葉日からの積算日射量が $400 \mathrm{MJ} / \mathrm{m}^{2}$ 以 上になると，新葉の硬化度が概ね一定になると推定され たが，一定值に達するまでの硬化度の推移には明らかな 品種間差異がみられた。

表 2 に示したロジスティック曲線のパラメータを用い て品種ごとの硬化特性の特徴を述べると, パラメータ $\mathrm{A}$

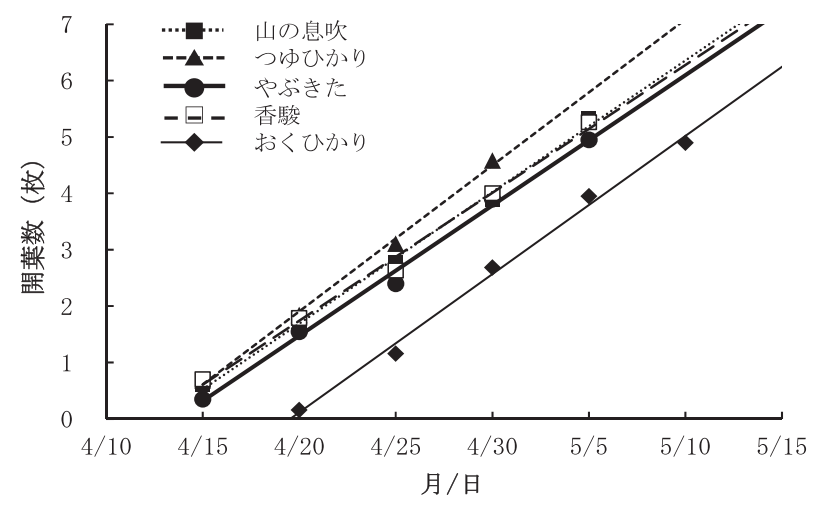

図 2 各品種の開葉数の推移（2012年）

回帰式の独立変数 $\mathrm{x}$ は起算日 $4 / 15$ からの経過日数, 従属変数 は開葉数の 20 芽平均值とした。

$$
\begin{array}{llll}
\text { 山の息吹 } & \mathrm{y}=0.233 \mathrm{x}+0.52 & (\mathrm{n}=5, & \left.\mathrm{r}^{2}=0.996\right) \\
\text { つゆかり } & \mathrm{y}=0.259 \mathrm{x}+0.61 & (\mathrm{n}=4, & \left.\mathrm{r}^{2}=0.997\right) \\
\text { やぶきた } & \mathrm{y}=0.231 \mathrm{x}+0.32 & (\mathrm{n}=5, & \left.\mathrm{r}^{2}=0.995\right) \\
\text { 香駿 } & \mathrm{y}=0.227 \mathrm{x}+0.61 \quad(\mathrm{n}=5, & \left.\mathrm{r}^{2}=0.993\right) \\
\text { おくひかり } & \mathrm{y}=0.245 \mathrm{x}-1.11 & (\mathrm{n}=5, & \left.\mathrm{r}^{2}=0.994\right)
\end{array}
$$

注）異なる英文字を付記した回帰式間には平行性検定による 有意差がある（holm法，5\%）。 

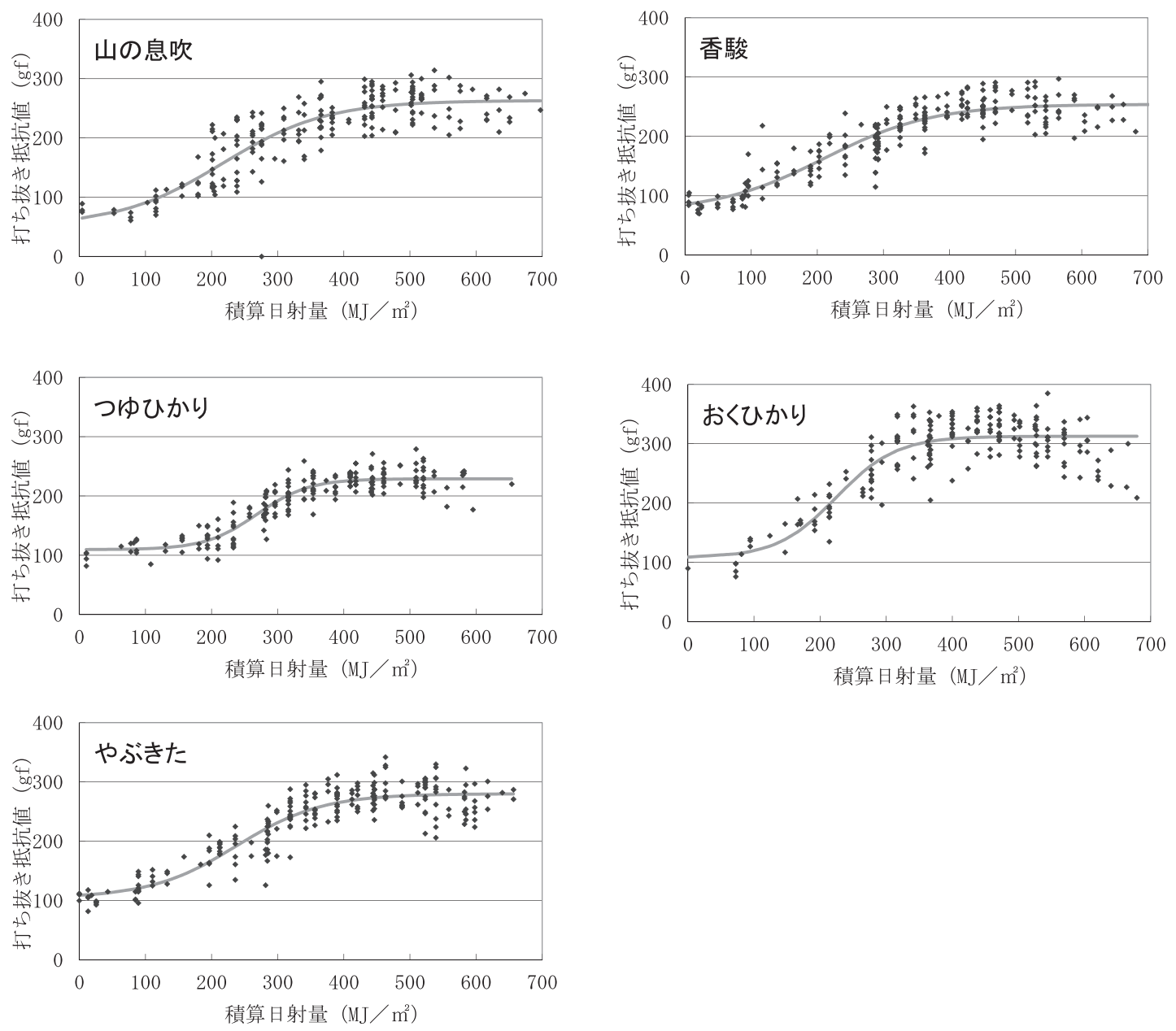

図 3 積算日射量と硬化度との関係（2011年）

表 2 ロジスティック曲線のパラメータの品種間差異

\begin{tabular}{|c|c|c|c|c|c|}
\hline パラメータ & 山の息吹 & つゆひかり & やぶきた & 香駿 & おくひかり \\
\hline A & 211.6 & 121.3 & 175.4 & 181.2 & 205.1 \\
\hline B & -2.8 & -6.7 & -3.7 & -2.6 & -5.0 \\
\hline $\mathrm{C}$ & 0.013 & 0.025 & 0.015 & 0.012 & 0.022 \\
\hline $\mathrm{D}$ & 51.5 & 109.0 & 104.6 & 72.8 & 107.4 \\
\hline$A+D$ & 263.1 & 230.3 & 280.0 & 254.1 & 312.6 \\
\hline $\begin{array}{l}\text { ロジステ } \\
\mathrm{Y}: \text { 従属 } \\
\mathrm{X}: \text { 独立 } \\
\mathrm{A} \text { : 硬化 } \\
\mathrm{B} \text { : 硬化 } \\
\mathrm{C}: \text { 相対 } \\
\mathrm{D}: \text { 開葉 } \\
\mathrm{A}+\mathrm{D}: \text { 最 }\end{array}$ & $\begin{array}{l}\text { ツク曲線： } \\
\text { 效（新葉打 } \\
\text { 效（開葉後涀 } \\
\text { 間中の全硬 } \\
\text { 台時期を規定 } \\
\text { 率（硬化连 } \\
\text { 新葉硬似 } \\
\text { 硬化度 }\end{array}$ & 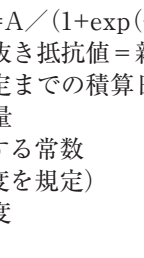 & $\begin{array}{l}3+\mathrm{C} \times \mathrm{X}())) \\
\text { 硬化度 }) \\
\text { 量 }=\text { 時間轅 }\end{array}$ & & \\
\hline
\end{tabular}

は, 開葉から硬化までの期間の全硬化量すなわち開葉直 後の上位葉と硬化の進んだ下位葉との硬化度の差を示し ており, ‘つゆひかり’が最も小さく, “山の息吹, おく ひかり’が大きかった。パラメータDは，開葉直後の硬 化度すなわち最上位葉の硬化度を示しており，“山の息 吹, 香駿’ が小さく, ‘やぶきた, つゆひかり, おくひ かり’ が大きかった。 $\mathrm{A}+\mathrm{D} は$ ，最終硬化度すなわち成
熟の進んだ最下葉の硬化度を示しており，‘つゆひかり’ が小さく，‘やぶきた，おくひかり’が大きかった。D と $\mathrm{A}+\mathrm{D}$ の関係からみた各品種の硬化特性を図 4 に示し たところ，‘やぶきた’ と比較して最終硬化度が大きい “おくひかり’と小さい‘つゆひかり’, 最終硬化度が ‘や ぶきた’ と同等だが開葉直後の硬化度が小さい“山の息 吹, 香駿’ という 3 タイプに分類された。また, 硬化開 


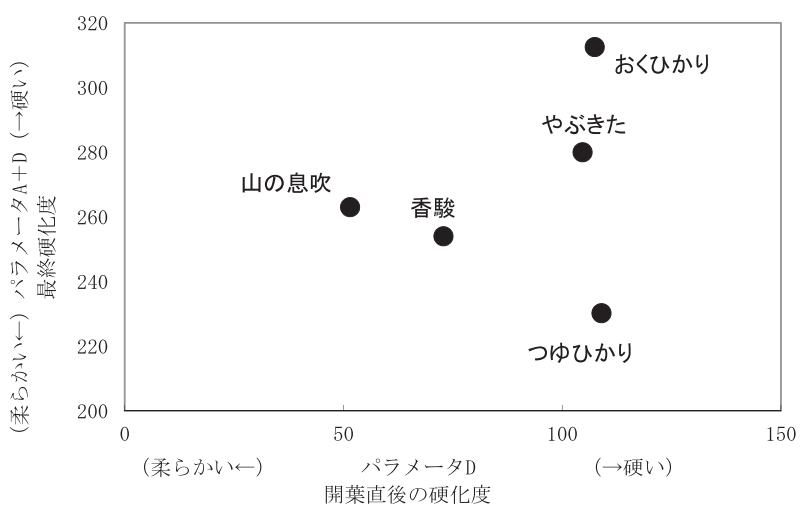

図 4 開葉直後の硬化度と最終硬化度からみた各品種の硬化特性（2011年）

始時期Bと硬化速度Cからみた硬化特性により, ‘やぶき た’と比較して, 硬化開始時期が遅く硬化速度が速い ‘つ ゆひかり，おくひかり’と硬化開始時期が早く硬化速度 が遅い ‘山の息吹, 香駿”という 2 タイプに分類された (図 5 )。なお, 本研究では品種ごとの硬化パターンをロ ジスティック曲線で表すため，下位の新葉が成熟する （すなわち $\mathrm{A}+\mathrm{D}$ 值がほぼ一定になる）まで生育させて硬 化度を測定した。このため, 図 3 における実際の摘採適 期は， 1 心 $4 \sim 5$ 葉期の下位葉の打ち抜き抵抗值（図 6 参照）を目安とすると, ‘つゆひかり, 香駿’では打ち 抜き抵抗值（Y軸）100～150gf，“山の息吹，やぶきた， おくひかり’では130～180gfの付近にある点には留意を 要する。

新芽の各生育ステージにおける葉位別の硬化度を図 6 に示した。‘やぶきた’ と比較すると, 上位葉（ 1 〜 2

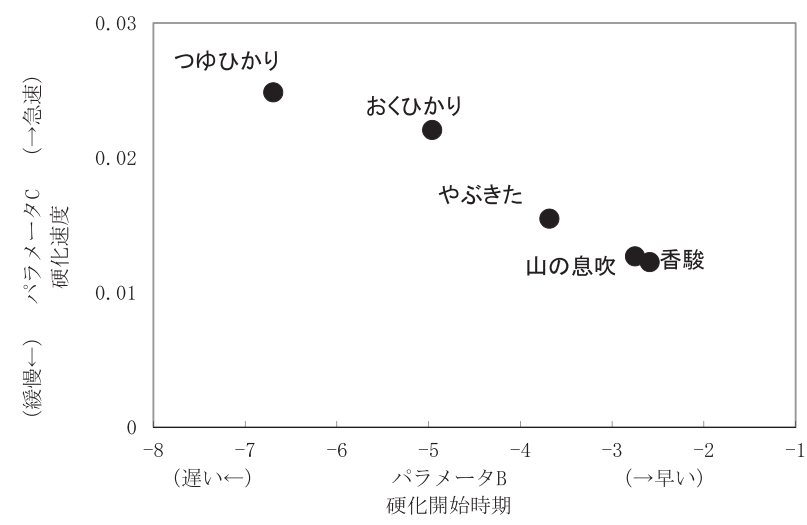

図 5 硬化速度と硬化開始時期からみた各品種の硬化特性（2011年）

葉位) の硬化度は, 総じて“香駿”が小さく, “山の息吹, つゆひかり’が同等，“おくひかり’が大きく，中位葉 $(3$ ～4 葉位) の硬化度は, “香駿，つゆひかり’が小さく， “山の息吹, おくひかり’ が同等で, 下位葉（ 5 〜 6 葉 位）の硬化度は, ‘香駿，つゆひかり’が小さく，“山の 息吹，おくひかり’が大きかった。ただし，“おくひか り’の 6 葉位の硬化度が大きかった点には採取日が遅か ったことも影響したと考えられた。また，‘つゆひかり’ では，上位葉と下位葉の硬化度の差が小さい点に特徵が あり，この特徵は上述した2011年の試験結果（図 3 , 表 2 のA值）と一致した。

\section{3 生育に伴う新芽の全窒素含有率の変動}

収量の指標である摘芽重および品質の指標である摘芽 の全窒素含有率はともに, 生育時期によって大きく変化

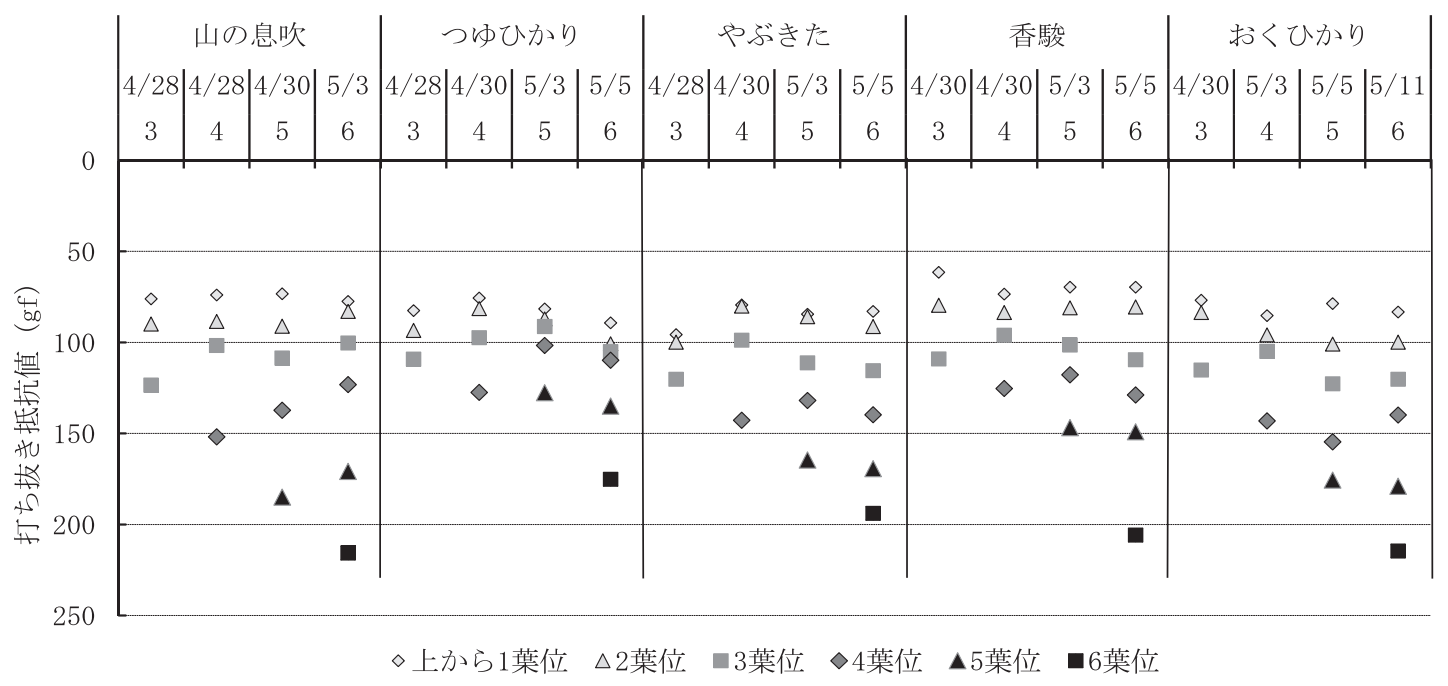

図 6 生育ステージ別, 葉位別の硬化度にみられる品種間差異 (2012年)

注 1 ） 5 芽の平均值。

注 2 ）日付は採取日、日付の下は採取葉位、例：「3」は 1 心 3 葉芽。 
する特性があることから, 早晚性の異なる品種間で品質 特性を正確に比較するためには, 品種ごとの適期に摘採 するか収量レベルを揃えて比較するといった工夫が必要 である。そこで本研究では, 過去の知見 ${ }^{9 \sim 11)}$ を参考と して, 摘採適期前後の摘芽重と全窒素含有率を経時的に 調查し, 両者の関係を表す 1 次回帰式から, 収量が同一 となる時点の推定全窒素含有率を求めて比較した。まず 各品種の枠摘み摘芽重の推移を図 7 に示した。11～12日 間の調查期間中に各品種の摘芽重（乾燥重）は概ね $2.5 \mathrm{~g}$ から $10 \mathrm{~g}$ まで増加し, 独立変数を 4 月 28 日からの経過日 数, 従属変数を摘芽重として, 品種ごとに回帰直線を作 成した結果, 摘芽重の増加速度は, 速い順に “扔くひか り>香駿＞やぶきた＞山の息吹＞つゆひかり’となり， 回帰直線の平行性検定を行なった結果, ‘つゆひかり’ と“抽くかり”との間に有意差が認められた。次に， 各品種の枠摘み摘芽重と全窒素含有率の関係を図 8 に示 した。各品種とも枠摘み摘芽重と全窒素含有率との間に 強い負の相関関係がみられ，枠摘み摘芽重の増加に伴い 全窒素含有率が低下した。独立変数を摘芽重, 従属変数 を全窒素含有率として品種ごとに回帰直線を作成し, 平 行性検定を行った結果, 回帰直線の傾きが小さい順につ ゆひかり<香駿＜やぶきたくおくひかりく山の息吹'と なり，‘つゅひかり の傾きは，“山の息吹，やぶきた， おくひかり’よりも有意に小さかった。10a当たりの生

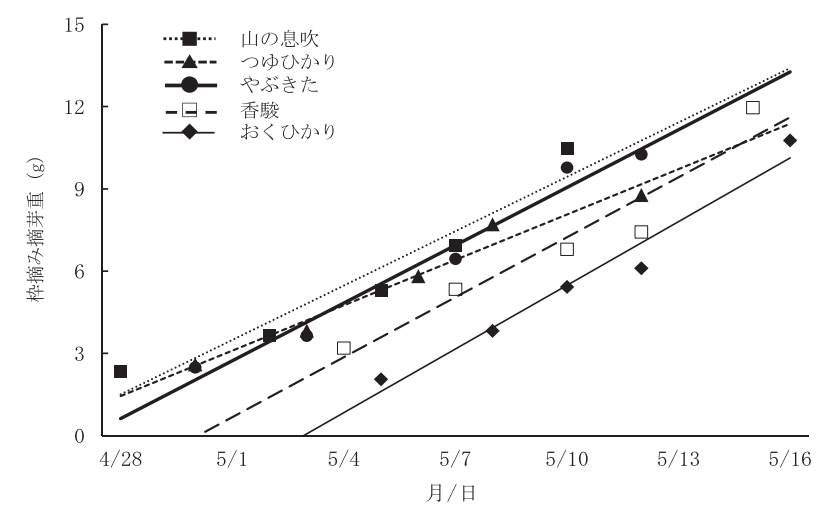

図 7 一番茶の枠摘み摘芽重の推移（2011年）

回帰式の独立変数 $\mathrm{x}$ は起算日 $4 / 28$ からの経過日数, 従属変数 は摘芽重の 4 枠平均值とした。

$$
\begin{aligned}
& \text { 山の息吹 } \mathrm{y}=0.661 \mathrm{x}+0.85(\mathrm{n}=5, \mathrm{r}=0.96) \mathrm{ab} \\
& \text { つゆひかり } \mathrm{y}=0.551 \mathrm{x}+0.90(\mathrm{n}=5, \quad \mathrm{r}=0.98) \mathrm{a} \\
& \text { やぶきた } \quad \mathrm{y}=0.702 \mathrm{x}-0.07(\mathrm{n}=5, \quad \mathrm{r}=0.99) \mathrm{ab} \\
& \text { 香駿 } \quad \mathrm{y}=0.729 \mathrm{x}-2.24(\mathrm{n}=5, \quad \mathrm{r}=0.96) \mathrm{ab} \\
& \text { おくひかり } \mathrm{y}=0.774 \mathrm{x}-4.58(\mathrm{n}=5, \quad \mathrm{r}=0.98) \mathrm{b}
\end{aligned}
$$

注 1 ）異なる英文字を付記した回帰式間には平行性検定によ る有意差がある（holm法， 5\%)。

注 2 ) 枠摘み摘芽重は, $20 \times 20 \mathrm{~cm}$ 枠内摘芽の乾燥重。
葉収量を $600 \mathrm{~kg}$ と仮定した場合, 枠摘み摘芽重（乾燥 重）は約 $5 \mathrm{~g}$ と算出され，この值を回帰直線に当てはめ ると, 各品種の推定全窒素含有率は高い順につつゆひか り (6.35\%) >やぶきた（6.25\%）＞おくひかり（6.16\%） $>$ 香駿 $(6.13 \%)>$ 山の息吹 $(6.12 \%)$ となった。

各品種の生育ステージと全窒素含有率の関係を図 9 に 示した。各品種とも生育ステージの進展に伴い全窒素含 有率は概ね低下した。‘つゆひかり’は 1 心 4 葉から 1 心 6 葉にかけての全窒素含有率の低下程度が小さかった が, 他の 4 品種は低下程度が大きかった。同一生育ステ ージの ‘やぶきた’と比較すると, ‘つゆひかり, 香駿” は 1 心 4 葉から 1 心 6 葉にかけて全窒素含有率が有意に 高く, ‘おくひかり’ は, 1 心 5 葉から 1 心 6 葉にかけ て有意に低かった。ただし，“おくひかり’の 1 心 6 葉 芽の全窒素含有率が低かったのは, 採取日が遅かったこ とも影響したと考えられた。

\section{4 考察}

開葉直後から成熟期までの経時的な新芽葉の硬化パ夕 ーンには明らかな品種間差異がみられ, 開葉直後の硬化 度, 最終硬化度, 硬化開始時期, 硬化速度の各要素を用 いて品種ごとの硬化特性を分類できた。渡辺 ${ }^{8)}$ が 9 品 種を供試した試験では硬化開始時期が遅い品種は硬化速

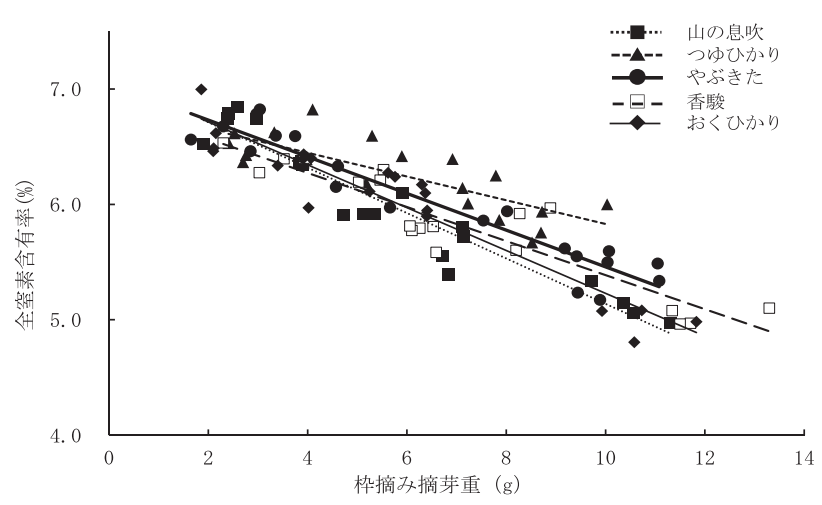

図 8 一番茶の枠摘み摘芽重と全窒素含有率の関係（2011年）

回帰式の独立変数 $\mathrm{x}$ は枠摘み摘芽重, 従属変数は全窒素含有 率含有率とした。

$$
\begin{array}{lllll}
\text { 山の息吹 } & \mathrm{y}=0.197 \mathrm{x}+7.1 & (\mathrm{n}=20, & \mathrm{r}=0.96) & \mathrm{b} \\
\text { つゆか } & \mathrm{y}=0.103 \mathrm{x}+6.9 & (\mathrm{n}=20, & \mathrm{r}=0.80) & \mathrm{a} \\
\text { やぶきた } & \mathrm{y}=0.159 \mathrm{x}+7.0 & (\mathrm{n}=20, & \mathrm{r}=0.95) & \mathrm{b} \\
\text { 香駿 } & \mathrm{y}=0.148 \mathrm{x}+6.7 & (\mathrm{n}=19, & \mathrm{r}=0.88) & \mathrm{ab} \\
\text { おくひかり } & \mathrm{y}=0.186 \mathrm{x}+7.1 & (\mathrm{n}=20, & \mathrm{r}=0.95) & \mathrm{b}
\end{array}
$$

注 1 ）異なる英文字を付記した回帰式間には平行性検定によ る有意差がある（holm法，5\%）。

注 2$)$ 枠摘み摘芽重は, $20 \times 20 \mathrm{~cm}$ 枠内摘芽の乾燥重。 


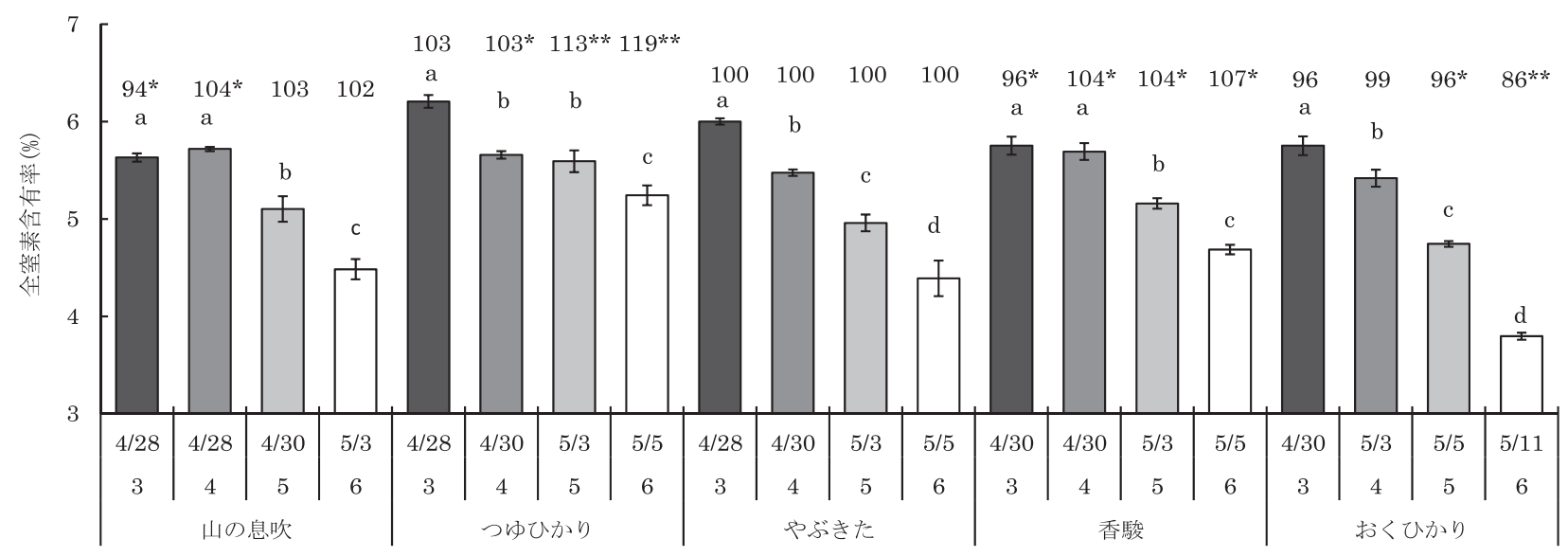

図 9 新芽の生育ステージと全窒素含有率との関係（2012年）

注 1$)$ エラーバーは標準偏差 $(n=3)$ 。棒グラフ上の数值は同葉位の ‘やぶきた’を100とした場合の各品種の相対値，アス夕 リスクは同葉位の ‘やぶきた’との有意差 ( $\mathrm{t}$ 検定; $\left.{ }^{*} 5 \%,{ }^{* *} 1 \%\right)$, 英文字は同一品種内での有意差 (tukey $5 \%$ ) を示す。 注 2）10芽採取し乾燥粉砕後、全窒素の分析に供した。

注 3 ）日付は採取日。日付の下は採取葉位を表す。例：「3」は 1 心 3 葉芽。

度が速いとの関係が示されており（例：さやまかおり）, 本研究でも ‘つゆひかり’や‘おくひかり’で同様の傾 向がみられた。一般的な摘採適期と考えられる 4 〜葉 期における中・下位葉の硬化度を品種間で比較すると, ‘つゆひかり, 香駿”は‘やぶきた’よりも硬化度が小 さく，“山の息吹，おくひかり’は‘やぶきた’と同等 か大きかった。さらに ‘つゆひかり’は上位葉と下位葉 の硬化度の差が小さかった。以上のような葉位別の硬化 度の品種間差異は, 新葉の硬化パターンの違いに基づい て生じると推察された。

経時的な枠摘み調查結果から, 枠摘み摘芽重の増加速 度は, ‘おくひかり’ が速く, ‘つゆひかり’が遅く, 開 葉速度とは一致しなかった。各品種とも生育ステージの 進展や摘芽重の増加に伴い全窒素含有率は低下したが, ‘つゆひかり’ は他の品種よりも全窒素含有率の低下が 緩慢であり，摘採適期における全窒素含有率が高かった。 ‘つゆひかり’の一番茶の荒茶中の窒素成分含量が ‘や ぶきた, さやまかおり’等の品種よりも高いことは複数 報告 ${ }^{12,13)}$ されており，本結果と一致した。

以上のことから， ‘つゆひかり’は他の 4 品種とは明 瞭に異なる硬化特性および成分変動特性を有しているこ とが示された。そこで, その特徵を以下に整理してみる。 ‘つゆひかり’ は開葉速度が速いが, 摘芽重の増加速度 が遅いため, 同一収量時の新芽葉数が多い。また, 摘芽 重の増加に伴う全窒素含有率の低下が遅く, 摘採適期に おける全窒素含有率が高い。‘やぶきた’ と同程度の収 量を得られる時期の新芽葉数は‘やぶきた’より多く,
全窒素含有率は‘やぶきた’より高い。‘やぶきた’ と 同程度の全窒素含有率となる時期の収量は ‘やぶきた” より多い。どちらの時期も硬化度は ‘やぶきた’より小 さく, 上位葉と下位葉の硬化度の差も小さい。したがっ て, 収穫期の幅が広く収穫時期が遅れた場合の品質低下 が小さいといえる。

なお, 本研究では, 年次が異なる単年度の試験結果を 基に品種間差異を考察したため, 同じ特性でも傾向が一 致しない部分があった。また, ‘つゆひかり’ 以外の品 種については‘やぶきた’ との差異が判然としない部分 があった。新芽の化学成分含量の品種間差異を明確にす るためには年次変動の解析も必要であることが指摘され ている ${ }^{14)}$ 。生育・硬化特性, 成分特性およびそれらの相 互関係について, より普遍的な傾向を得るためには, 供 試品種数を増加し, 年次試験を重ねた上で改めて論じる 必要があると考える。

\section{5 摘 要}

静岡県奨励 4 品種について, 一番茶新芽の生育, 硬化, 成分に関する特性を ‘やぶきた’ と比較した。開葉速度 は, 速い順に ‘つゆひかり>おくひかり>やぶきたう山 の息吹 >香駿 となる傾向が示された。硬化パターンお よび葉位別硬化度には明瞭な品種間差異がみられ, 同一 葉期で比較すると, 摘採適期前後（ 4 ～5 葉期）の硬化 度は低い順に， ‘歽く香駿＜やぶきたく山の息 吹くおくひかり’となった。生育ステージの進展や摘芽 
重の増加に伴う新芽の全窒素含有率の低下程度および同 一摘芽重または生育ステージでの全窒素含有率には品種 間差異がみられた。‘やぶきた’ と比較すると ‘つゆひ かり’ は摘採期の全窒素含有率が高く低下速度が緩慢で あった。

\section{6 引用文献}

1 ）此本晴男（1980）：チャの新芽の熟度判定法. 茶研報, No.52, 11-18.

2 ）田中静夫・佐波哲次・渡辺利通（1990）：チヤ新芽の木化の進 行と茶品質との関係。茶研報, No.72（別），26-27.

3 ) 松尾喜義・池田奈実子 - 岡野邦夫 - 吉田魏・渡辺利通（1993）: チャ葉の “かたさ”測定について. 茶研報, No.78 (別), 38-39

4) 佐波哲次・渡辺利通（1993）：チャ新芽茎の針貫入抵抗力と挫 折力および木化程度との関係．茶研報，No.78（別)，40-41.

5 ) 渡辺利通・吉田魏（1996）：打ち抜き抵抗測定器の開発と硬化 度の葉内変異. 茶研報, No.84（別), 10-11.
6 ）根角厚司・四方秀幹・池田奈実子（1999）：一番茶期におけ る新葉の硬化度と化学成分含有量の品種特性. 茶研報, No.88 (別), 22-23.

7 ）武弓利雄・佐波哲次（1999）：一番茶新芽硬化度の部位および 品種による違い。茶研報, No.88 (別), 20-21.

8 ) 渡辺利通 (2000)：チャ新芽硬化パターンの品種間差異. 茶研 報, No.90（別），88-89.

9 ）中村充・小川茂（1987）：茶園土壤の物理性改善が茶樹の生育 及び新芽の窒素含量におよぼす影響. 静岡茶試研報，13，6170.

10）成島光昭・青山正巳（2006）：環境に配虑した茶園施肥が茶の 生育・収量に及ぼす影響，茶研報、No.102（別），36-37.

11）大石哲也 (2011): 凍霜害被害茶園に扔ける被害程度と摘芽重, 摘採期との関係．茶研報, No.112（別），22-23.

12）小栁津勤・倉貫幸一 - 中村順行 - 日高保 - 青島洋一（2003）： 新しい煎茶用品種 ‘つゆひかり’。茶研報, No.95，1-15.

13）片井秀幸 - 鈴木利和 - 佐藤光 - 小栁津勤（2014）：強遮光下に おける静岡県奨励品種の特性. 茶研報, No.118（別），20-21.

14）池田奈実子 · 堀江秀樹 - 向井俊博 ・後藤哲久（2006）：チャ品 種の一番茶新芽の化学成分含有量の年次変動. 日作紀, 75 , 511-517. 